Butwal Campus Journal, Vol. 3, No. 1: 1-20, July 2020

Research Management Cell, Butwal Multiple Campus, Tribhuvan University, Nepal

\title{
TRADE OPENNESS AND ECONOMIC GROWTH IN NEPAL
}

\author{
Surya Bahadur Rana* \\ *Assistant Professor, Butwal Multiple Campus, Butwal, TU
}

Article History: Received 5 May 2020; Reviewed 25 May 2020; Revised 28 June 2020; Accepted 02 July 2020

\begin{abstract}
This study examines the impact of trade openness on economic growth in Nepal over the period 1975-2019. Using ARDL bounds testing approach to cointegration in the multivariate framework, the study results reveal that there exists a long-run relationship between Nepal's foreign trade and economic growth over the study period. The long-run estimates of ARDL model show that the level of trade openness in Nepal predicts the rate of economic growth of the country positively and significantly in the long-run. The study also reports the positive and significant longrun effect of investment level on growth in Nepal over the study period supporting the tradeinduced investment growth hypothesis. It postulates that trade openness affects economic growth through the channel of investment. The growth enhancing role of trade openness implies that Nepal Government should promote international trade by eliminating trade barriers and making the procedures of foreign trade simple and convenient. Besides, Nepal's import policy should promote investment environment particularly in capital intensive sectors to take the advantage of technology transfer from technologically advanced country. Furthermore, Nepal should pay proper attention and come up with effective human resource development policy that can uplift human knowledge and skills to make use of technologies from developed countries.
\end{abstract}

Keywords: ARDL - export - growth - import - trade openness.

\section{INTRODUCTION}

The nexus between trade openness and economic growth has received considerable attentions in empirical arena since the works of Grossman and Helpman (1990), and Romer 
(1990), among others. The empirical debates on trade-growth nexus mainly centers on tradeled growth hypothesis, which advocates that a country with higher level of trade openness achieves speedy rate of economic growth. Rivera-Batiz and Romer (1991), and Barro and Sala-I-Martin (1997) postulate that higher level of trade openness in an economy promotes people's access to products and services, increases efficiency in resource allocation, diffuses technology, and disseminates knowledge. Such advancement in the economy ultimately improves total factor productivity leading to a faster pace of economic growth. Many of the empirical evidences at cross-country level as well as country-specific level establish the positive linkage between the level of trade openness and economic growth supporting the hypothesis that the level of trade openness in an economy positively and significantly influences the rate of economic growth. For example, some of the earlier studies such as Sengupta and Espana (1994), McCarville and Nnadozie (1995), and Bodman (1996), among others, confirm that level of trade openness positively impacts the growth. In an investigation into trade-growth nexus across a panel of 150 countries, Rassekh (2007) finds that countries with lower level of income are benefited more by trade openness to accelerate growth than their higher income counterparts. In contrast, using the instrumental variable estimation method to investigate the nexus between trade and growth, Kim, Lin, and Suen (2011) report positive effect of trade openness on growth in case of high-income countries, while negative effect in case of low-income countries. On the other hand, Chang et al. (2009) support the hypothesis of trade-led growth in a cross-country study involving 82 countries.

Besides, studies in more recent periods have also documented significant impact of trade openness on economic growth. For example, Nowbutsing (2014), and Keho (2017), among others, report the positive impact of trade openness on economic growth both in the long-run and short-run. Similarly, using various measures of trade openness to examine their impact on economic growth in case of South Africa, Malefane and Odhiambo (2018) show that total trade affects economic growth in the long-run, while other measures do not. However, the short-run estimates show that three measures of trade openness, namely total trade, imports, and exports, all affect economic growth significantly.

In contrast to the trade-led growth hypothesis, some studies such as Vamvakidis (2002), Rigobon and Rodrik (2005), and Ulasan (2015) find week evidences to support tradeled growth. Similarly, in case of a cross-country study using a panel of 27 least developed countries, Tekin (2012) reports no significant causality between trade openness and GDP growth. Studies have also attempted to identify the channel through which trade openness can 
influence economic growth. For example, in case of a panel of 16 developing countries, Gries et al. (2009) report that the trade openness affect economic growth through the channel of financial deepening as such that the countries with higher level of financial deepening are more able to speed up the rate of economic growth by opening their economies to international trade. Similarly, using a sample of 46 countries, Huang and Chang (2014) report that the effect of trade openness on growth depends on the level of a country's stock market development. The study shows that a country with high level of stock market development achieves higher impact of trade openness on growth.

Thus, cited literatures show the mixed evidences on the trade-growth nexus. Such differences in results are attributed to many factors. For example, one possible reason may be that studies involving cross-country samples may not recognize the heterogeneity across countries included in the sample list. In fact, each country is unique in terms of development state of technology, economic structure, institutional development, and trade policy. Besides, some countries may be import-oriented, while others may be export-oriented. So, it may not be logical to ignore the cross-country heterogeneity. Recognizing these problems associated with cross-country samples, an attempt has been made in this study to examine the impact of trade openness on economic growth using Nepal as a country specific case.

Moreover, the differences in results are also attributed to the proxies used for trade openness in the studies. Most of the cited literatures in case of developed countries are in support of export-led growth hypothesis, which use value of exports as the proxy of trade openness. It is apparent that developed economies generally have higher shares of exports to their total volume of foreign trade. So, exports contribute significantly to accelerate the pace of their economic growth. However, the role of imports cannot be overlooked, particularly, in case of underdeveloped and developing countries. With respect to the effects of imports on growth, Coe and Helpman (1995) suggest that higher degree of openness of the economy tends to improve more technological progress and attract more income and savings thus contributing positively towards productivity growth of the nation. They further argue that imports contribute positively toward growth by facilitating the use of novel technologies. Particularly, other things held constant, the countries with higher imports of capital goods are faster in achieving output growth. Furthermore, Barro and Sala-I-Martin (1997) emphasize that underdeveloped and developing nations can have access to new technology, knowledge, and competitive products and services through imports that make their resource allocation efficient leading to improvements in total factor productivity and output growth. 
Nepal is traditionally an import-oriented economy. It relies heavily on imports of capital and consumable goods as significant part of its total volume of foreign trade. As reported in Figure 1, the growth in per capita real import (PCrIMP) in Nepal over 1975-2019 periods follow almost the same pattern as the growth in per capita real GDP (PCrGDP), while the growth in per capita real export (PCrEXP) is almost stagnant over the same period.

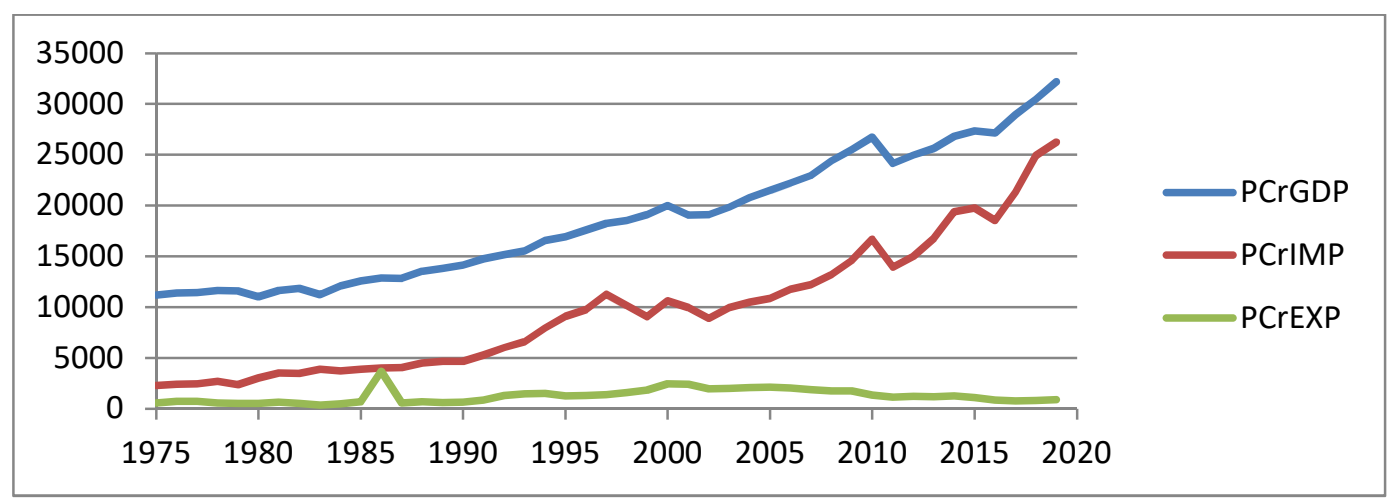

Source: Constructed using the data derived from sources described in Section 2.

Figure 1: Per capita real GDP, real import and real export, 1975-2019

As reported in Table 1, the share of per capita real import to per capita real GDP has been increased from 20.27 percent in the year 1975 to 81.48 percent in 2019 accounting for average 46.84 percent share over 1975-2019. On the other hand, share of per capita real export to per capita real GDP has been declined from 4.99 percent to 2.80 percent accounting for only 6.90 percent average share over the same period. The average per capita real import growth has been recorded at 5.72 percent over the review period, while it is only a tiny 1.09 percent for per capita real export, and 2.43 percent for per capita real GDP.

These facts show that share of Nepal's foreign trade has increased to almost four-fifth of the GDP in recent year in per capita real value terms. The share of total external trade to GDP was about 37 percent in the 1990, which increased to about 61 percent in the first half of 1990 s, when government accelerated economic liberalization. Increased share of foreign trade indicates that Nepal is marching towards global economic integration through the foreign trade. At the same time, it also indicates that Nepal is being more dependent on global economy as significant portion of foreign trade has been dominated by the value of imports. In these backdrops, this study takes into account total value of both imports plus exports as the proxy of trade openness. Besides, this study uses more recent dataset to examine the 
performance of Nepal's foreign trade on accelerating country's rate of economic growth. Therefore, the main objective of this study is to investigate the impact of Nepal's trade openness on economic growth taking into account the total value of foreign trade as the proxy of trade openness. In addition, the study also attempts to test whether the trade-led growth in case on Nepal is a short-run or long-run phenomenon.

Table 1: Per capita real import and export as a share of per capita real GDP

\begin{tabular}{cccccc}
\hline Year & IMP/GDP & EXP/GDP & Year & PCrIMP & PCrEXP \\
\hline $\mathbf{1 9 7 5}$ & 0.2027 & 0.0499 & $\mathbf{1 9 7 5}$ & 2270.74 & 559.54 \\
$\mathbf{1 9 8 0}$ & 0.2763 & 0.0459 & $\mathbf{1 9 8 0}$ & 3048.11 & 506.61 \\
$\mathbf{1 9 8 5}$ & 0.3081 & 0.0548 & $\mathbf{1 9 8 5}$ & 3871.71 & 688.82 \\
$\mathbf{1 9 9 0}$ & 0.3285 & 0.0464 & $\mathbf{1 9 9 0}$ & 4652.16 & 657.76 \\
$\mathbf{1 9 9 5}$ & 0.5386 & 0.0750 & $\mathbf{1 9 9 5}$ & 9114.89 & 1268.73 \\
$\mathbf{2 0 0 0}$ & 0.5300 & 0.1223 & $\mathbf{2 0 0 0}$ & 10611.41 & 2448.50 \\
$\mathbf{2 0 0 5}$ & 0.5047 & 0.0996 & $\mathbf{2 0 0 5}$ & 10849.86 & 2141.35 \\
$\mathbf{2 0 1 0}$ & 0.6245 & 0.0510 & $\mathbf{2 0 1 0}$ & 16685.45 & 1362.38 \\
$\mathbf{2 0 1 5}$ & 0.7237 & 0.0401 & $\mathbf{2 0 1 5}$ & 19781.75 & 1094.80 \\
$\mathbf{2 0 1 9}$ & 0.8148 & 0.0280 & $\mathbf{2 0 1 9}$ & 26229.84 & 902.33 \\
\hline & & $\mathbf{0 . 0 6 9 0}$ & Annual & & $\mathbf{0}$ \\
Average & $\mathbf{0 . 4 6 8 4}$ & Growth & $\mathbf{0 . 0 5 7 2}$ & $\mathbf{0 . 0 1 0 9}$ \\
\hline
\end{tabular}

Source: Calculated using the data derived from sources described in Section 2.

The rest of this paper is organized as follows: section two describes the model, data source, and empirical methodology including definition and measurement of variables used; section three presents study results and discussion on findings; and finally, section four concludes and presents major implications of the study.

\section{RESEARCH METHODS}

\section{The model}

As stated before, the basic objective of this study is to examine the role of trade openness in predicting economic growth in Nepal. To capture the potential effects of the level of Nepal's foreign trade on economic growth, this study uses the framework suggested by endogenous growth model of Romer (1986), Rebelo (1991) and Pagano (1993). Under this 
framework, total output growth, in the long-run, is determined by growth in total factor productivity (TFP), which in turn is affected by growth rate of technological progress as given in Equation (1).

$\mathrm{Q}_{\mathrm{t}}=\mathrm{A}_{\mathrm{t}}\left(\mathrm{K}_{\mathrm{t}}\right)^{\alpha}\left(\mathrm{L}_{\mathrm{t}}\right)^{1-\alpha}$

In Equation (1), 'Q' represents total output growth at period t, 'A' is the rate of technological progress, ' $\mathrm{K}$ ' is the capital stock and, ' $\mathrm{L}$ ' is the stock of human capital. The rate of technological progress can be affected by the level foreign trade of a country including several other factors. Under this assumption, the rate of technological progress can be written as follows:

$\mathrm{A}_{\mathrm{t}}=\Phi\left(\mathrm{T}_{\mathrm{t}}\right)^{\delta}\left(\mathrm{Z}_{\mathrm{t}}\right)^{\rho}$

In Equation (2), ' $T$ ' stands for the level of total foreign trade, and ' $Z$ ' stands for all other factors that are likely to affect the level of technological progress. Substituting Equation (2) into (1), we obtain Equation (3) as follows:

$\mathrm{Q}_{\mathrm{t}}=\Phi\left(\mathrm{T}_{\mathrm{t}}\right)^{\delta}\left(\mathrm{K}_{\mathrm{t}}\right)^{\alpha}\left(\mathrm{L}_{\mathrm{t}}\right)^{1-\alpha}\left(\mathrm{Z}_{\mathrm{t}}\right)^{\rho}$

Now, dividing Equation (3) by total population size and taking natural logarithm, the Equation (3) can be re-written as follows:

$\operatorname{LnGDP}_{\mathrm{t}}=\theta_{0}+\theta_{1} \operatorname{LnTRADE}_{\mathrm{t}}+\theta_{2} \operatorname{LnCAP}_{\mathrm{t}}+\theta_{3} \mathrm{LnPOP}_{\mathrm{t}}+\mu_{\mathrm{t}}$

In Equation (4), 'LnGDP' is the natural logarithm of per capita real GDP used as a proxy of economic growth, 'LnTRADE' is the natural logarithm of per capita real value of total foreign trade used as a proxy of trade openness, 'LnCAP' is the natural logarithm of per capita real capital stock, and 'LnPOP' is the natural logarithm of total population size. One problem associated with using Equation (4) is that the time series data on capital stock are not instantly available for most of the developing countries, and so is the case of Nepal. Some studies, such as King and Levine (1993) and Levine and Zerovs (1998), base their estimates of capital stock assuming zero level of initial capital stock. However, this assumption also does not give actual level of capital stock. Therefore, following Ghura (1997) and Beddies (1999), the investment has been used instead of capital stock. Thus, Equation (4) can be restated in the following form:

$\mathrm{LnGDP}_{\mathrm{t}}=\theta_{0}+\theta_{1} \operatorname{LnTRADE}_{\mathrm{t}}+\theta_{2} \mathrm{LnINV}_{\mathrm{t}}+\theta_{3} \mathrm{LnPOP}_{\mathrm{t}}+\mu_{\mathrm{t}}$ 
In Equation (5), 'LnINV' is the natural logarithm of per capita real investment measured as per capita real gross fixed capital formation.

\section{Data source}

The empirical analysis carried out in this study relies on annul time series data obtained from various sources. The annual time series data covers 45 years of period from mid-July 1975 to mid-July 2019. The annual nominal and real GDP series from mid-July 1975 to 2019 were obtained from 'A Hand Book of Government Finance Statistics, 2014 Vol. 5', 'A Hand Book of Government Finance Statistics, 2017 Vol. 5', and 'Macroeconomic Indicators of Nepal, November 2019' published by Nepal Rastra Bank (NRB). GDP deflators were calculated as new series of nominal GDP divided by real GDP using 100 as base value for the year 2000/01. GDP deflators so obtained were used to transform nominal values of other variables into the real term. The data on total value of import and export over the study period were derived from 'Quarterly Economic Bulletin Vol. 52, No. 3, Mid-April 2019' and 'Macroeconomic Indicators of Nepal, November 2019' published by NRB. Similarly, data on gross fixed capital formation were obtained from various issues of Economic Survey published by Government of Nepal, Ministry of Finance. Finally, total annual population data of Nepal were derived from 'National Population and Housing Census, 2011 (National Report), Vol. 1, 2012' published by Central Bureau of Statistics. The population data until mid-July 2010 were actual data. For mid-July 2011 and later periods, the medium variant population forecast has been used to project the population development.

\section{Definition and measurement of variables}

Economic growth: Economic growth is the dependent variable of this study. The rate of economic growth may be measured in several ways, such as in terms of per capita real GDP growth as in Levine and Zerovs (1996) and in terms of capital stock growth and productivity growth as in Levine and Zerovs (1998). As discussed before, the data on capital stock are unavailable in case of Nepal, and productivity growth can be determined only after obtaining the capital stock growth. Thus, this study employs the natural logarithm of per capita real GDP as a measure of economic growth, and is denoted as 'LnGDP'.

Trade openness: Trade openness is the main variable of interest in this study. It has been used as an independent variable to examine the long-run and short-run dynamics of the impact of Nepal's foreign trade on economic growth. Most of the previous studies conducted in the context of developed economies make use of data on values of exports as the proxy of trade 
openness and ignore the role of imports. However, as postulated in the theory of comparative advantage, developing and underdeveloped economies can take the advantage of better resource mobilization by importing technically advanced capital goods, which otherwise involves higher cost of production in domestic country (Yanikkaya, 2003). Nepal is basically an import-oriented economy. According to Macroeconomic Update of Nepal-2019, Volume 17 published by Asian Development Bank, Nepal's share of net exports on GDP accounts about 40 percent negative in the year 2018. Therefore, the share of imports on Nepal's foreign trade is very significant. Hence, this study uses total value of both imports and exports to capture the trade openness. This variable has been measured as natural logarithm of per capita real value of imports plus exports and denoted as 'LnTRADE'.

Other macroeconomic variables: Besides trade openness, the empirical model includes two other macroeconomic variables as regressors: investment and population size. Investment is the proxy of the level of real investment activity in the economy. It has been measured as natural logarithm of per capita real value of gross fixed capital formation and denoted as 'LnINV'. The investment variable has been included into the model as motivated by tradeinduced investment-led growth hypothesis, which postulates that the level of trade openness affects economic growth through the channel of investment. With respect to this hypothesis, Seghezza and Baldwin (2008) articulate that higher level of trade openness reduces cost of capital. Reduction in cost of capital in turn induces both increased demand for capital and return on investment that ultimately facilitates trade-induced investment growth.

Another macroeconomic variable included in the model is the total population size. The inclusion of population in the model can be interpreted as labor force that generates economic value added as other factors of production. However, literatures document controversial role with respect to the role of population in stimulating economic growth. Peterson (2017) articulates that role of population size in determining economic growth is sensitive to the income level of country. For example, lower population growth rate in high income country may not be sufficient to make optimum utilization of national resources which may cause socio-economic problems. On the other hand, higher rate of population growth in a low income country may obstruct its economic development process. On the contrary opinion, Simon (1990) argues that higher population growth creates larger stock of knowledge that contributes to the higher rate of economic growth. This argument is consistent to the notion of endogenous growth model. So, this study also uses population size denoted as 'LnPOP' as one of the macroeconomic variables in determining the level of Nepal's economic growth. 


\section{Empirical methodology}

This study makes use of ARDL bounds testing approach to cointegration to test empirically the long-run and short-run dynamics of the relationship between Nepal's foreign trade and economic growth. This approach was developed by Pesaran, Shin, and Smith (2001). This method of testing for long-run and short-run relationship among variables offers many advantages as compared to conventional Johansen and Juselius (1990) VECM based cointegration approach. First, ARDL bounds testing approach to cointegration can be applicable even if all variables are purely I(0) or purly I(1) or mixture of both; but none of the variables should be $\mathrm{I}(2)$. Second, the ARDL method estimates only a single reduced form equation (Pesaran \& Shin, 1995) as opposed to estimating the long-run relationship within the system of equation. Third, this method provides unbiased estimates of long-run relationship even if some of the regressors are endogenous (Odhiambo, 2011). Finally, this method can be efficiently applied even if the sample size is smaller. The basic representation of ARDL model is given in Equation (6).

$$
\begin{aligned}
& \Delta \operatorname{LnGDP}_{\mathrm{t}}=\beta_{0}+\sum_{\mathrm{i}=1}^{\mathrm{n}} \beta_{1 \mathrm{i}} \Delta \operatorname{LnGDP}_{\mathrm{t}-\mathrm{i}}+\sum_{\mathrm{i}=0}^{\mathrm{n}} \beta_{2 \mathrm{i}} \Delta \operatorname{LnTRADE}_{\mathrm{t}-\mathrm{i}}+\sum_{\mathrm{i}=0}^{\mathrm{n}} \beta_{3 \mathrm{i}} \Delta \operatorname{LnINV}_{\mathrm{t}-\mathrm{i}}+\sum_{\mathrm{i}=0}^{\mathrm{n}} \beta_{4 \mathrm{i}} \Delta \operatorname{LnPOP}_{\mathrm{t}-\mathrm{i}}+ \\
& \lambda_{1} \operatorname{LnGDP}_{\mathrm{t}-1}+\lambda_{2} \operatorname{LnTRADE}_{\mathrm{t}-1}+\lambda_{3} \operatorname{LnINV}_{\mathrm{t}-1}+\lambda_{4} \operatorname{LnPOP}_{\mathrm{t}-1}+\varepsilon_{\mathrm{t}}
\end{aligned}
$$

In Equation (6), the parameters $\beta_{1 \mathrm{i}}, \beta_{2 \mathrm{i}}, \beta_{3 \mathrm{i}}$, and $\beta_{4 \mathrm{i}}$, indicate the short-run dynamics of the model. On the other hand, parameters $\lambda_{1}, \lambda_{2}, \lambda_{3}$, and $\lambda_{4}$ represent the long-run relationship. The model tests the null hypothesis of no long-run relationship, where the null $\left(\mathrm{H}_{0}\right)$ is: $\lambda_{1}=\lambda_{2}$ $=\lambda_{3}=\lambda_{4}=0$. In this process, the ARDL bounds test is conducted to test for the null hypothesis of no co-integration. If calculated value of F-statistic is greater than upper bounds critical value, the test rejects the null of no cointegration meaning that there exists long-run relationship regardless of whether the underlying order of integration of the variable is $\mathrm{I}(0)$ or I(1) or mixture of both. On the other hand, if the calculated test statistic falls below the lower bounds critical value, the null hypothesis is not rejected. Finally, if the test statistic falls between upper and lower bounds critical values, the result is said to be inconclusive. The lag order of the ARDL model is selected based on Akaike Information Criterion and then the selected model is estimated by ordinary least square estimation method. After detecting the evidence of long-run relationship among the variables, the long-run model of Equation (7) is estimated. 


$$
\operatorname{LnGDP}_{t}=\beta_{0}+\sum_{j=1}^{n} \beta_{1 j} \operatorname{LnGDP}_{t-j}+\sum_{j=0}^{n} \beta_{2 j} \operatorname{LnTRADE}_{t-j}+\sum_{j=0}^{n} \beta_{3 j} \operatorname{LnINV}_{t-j}+\sum_{j=0}^{n} \beta_{4 j} \operatorname{LnPOP}_{t-j}+v_{t}
$$

After estimating the long-run model, the next step involves estimating error correction model (ECM). The ECM indicates the speed of adjustment back to long-run equilibrium if any short-run disequilibrium exists. The standard ECM involves estimating the Equation (8).

$$
\begin{aligned}
& \Delta \operatorname{LnGDP}_{\mathrm{t}}=\beta_{0}+\sum_{\mathrm{i}=1}^{\mathrm{n}} \beta_{1 \mathrm{i}} \Delta \operatorname{LnGDP}_{\mathrm{t}-\mathrm{i}}+\sum_{\mathrm{i}=0}^{\mathrm{n}} \beta_{2 \mathrm{i}} \Delta \operatorname{LnTRADE}_{\mathrm{t}-\mathrm{i}}+\sum_{\mathrm{i}=0}^{\mathrm{n}} \beta_{3 \mathrm{i}} \Delta \operatorname{LnINV}_{\mathrm{t}-\mathrm{i}}+\sum_{\mathrm{i}=0}^{\mathrm{n}} \beta_{4 \mathrm{i}} \Delta \mathrm{LnPOP}_{\mathrm{t}-\mathrm{i}}+ \\
& \lambda \mathrm{ECT}_{\mathrm{t}-1}+\varepsilon_{\mathrm{t}}
\end{aligned}
$$

Finally, diagnostic and stability tests of the model are conducted to confirm the goodness of fit of the model. The diagnostic tests involve examining the normality, serial correlation, and heteroscedasticity associated with the model residuals. Similarly, the stability tests involve employing the cumulative sum of recursive residuals (CUSUM) and the cumulative sum of squares of recursive residuals (CUSUMSQ) tests.

\section{STUDY RESULTS AND DISCUSSION}

\section{Descriptive statistics}

Table 2: Descriptive statistics

\begin{tabular}{lcccc}
\hline $\begin{array}{c}\text { Descriptive } \\
\text { Statistics }\end{array}$ & LnGDP & LnTRADE & LnINV & LnPOP \\
\hline Mean & 9.7770 & 9.1001 & 8.1320 & 2.9981 \\
Median & 9.8128 & 9.2992 & 8.1896 & 2.9982 \\
Maximum & 10.3794 & 10.2085 & 9.3834 & 3.3848 \\
Minimum & 9.3087 & 7.9481 & 7.2071 & 2.5521 \\
Std. Dev. & 0.3329 & 0.6688 & 0.5586 & 0.2398 \\
Skewness & 0.0846 & -0.2458 & 0.2646 & -0.1127 \\
Kurtosis & 1.6716 & 1.7859 & 2.3334 & 1.9750 \\
Jarque-Bera & 3.3622 & 3.2169 & 1.3583 & 2.0653 \\
p-value & 0.1862 & 0.2002 & 0.5070 & 0.3561 \\
Observations & 45 & 45 & 45 & 45 \\
\hline Source: Author's calculation using the data derived from sources described in Section 2.
\end{tabular}

Table 2 presents descriptive statistics associated with each of the variables over 19752019 periods. As can be seen, the LnGDP averaged at 9.7770 during the review period and 
reached maximum 10.3794 in the natural log form during the same period. Similarly, LnTRADE averaged at 9.1001 and reached all time high of 10.2085 in the natural log form during the study period. The Jarque-Bera test statistics for each of the variables do not reject the null of normality as their corresponding p-values are greater than 5 percent. This implies that all the variables in their natural log forms are normally distributed.

\section{Results of unit root tests}

Table 3: The results of ADF and PP tests

\begin{tabular}{|c|c|c|c|c|}
\hline \multicolumn{5}{|c|}{ Panel A: The Results of ADF Test } \\
\hline \multirow[b]{2}{*}{ Variables } & \multicolumn{2}{|c|}{ Intercept Only } & \multicolumn{2}{|c|}{ Trend and Intercept } \\
\hline & Level & $\begin{array}{c}\text { First } \\
\text { Difference }\end{array}$ & Level & $\begin{array}{c}\text { First } \\
\text { Difference }\end{array}$ \\
\hline LnGDP & 0.7655 & $-6.9364 *$ & -3.0815 & $-7.0883^{*}$ \\
\hline LnTRADE & -0.5177 & $-6.7294 *$ & $-3.6600 * *$ & $-6.6447 *$ \\
\hline LnINV & 0.6195 & $-4.1567 *$ & -1.6484 & $-4.4127 *$ \\
\hline LnPOP & -1.0176 & $-6.7459 *$ & -3.0388 & $-6.7234^{*}$ \\
\hline \multicolumn{5}{|c|}{ Panel B: The Results of PP Test } \\
\hline \multirow[b]{2}{*}{ Variables } & \multicolumn{2}{|c|}{ Intercept Only } & \multicolumn{2}{|c|}{ Trend and Intercept } \\
\hline & Level & $\begin{array}{c}\text { First } \\
\text { Difference }\end{array}$ & Level & $\begin{array}{c}\text { First } \\
\text { Difference }\end{array}$ \\
\hline LnGDP & 1.0313 & $-6.9695^{*}$ & -2.9837 & $-7.1758 *$ \\
\hline LnTRADE & -0.5627 & $-10.3881 *$ & $-3.6801 * *$ & $-10.2449 *$ \\
\hline LnINV & 1.2760 & $-8.8257 *$ & -1.8731 & $-9.0087 *$ \\
\hline LnPOP & -1.1188 & $-6.8107 *$ & -3.0908 & $-6.7956^{*}$ \\
\hline
\end{tabular}

Note: Reported values are test statistics under each of the unit root tests. "*” signs indicates that results are significant at 1 percent level, and “**” signs indicate that results are significant at 5 percent level.

Source: Author's calculation using the data derived from sources described in Section 2.

Before applying ARDL bounds testing approach to cointegration, first it is necessary to test for stationarity in time series data in order to confirm their order of integration. ARDL approach requires that dependent variables should be stationary at first difference, that is, they should be integrated of order one, I(1). Similarly, this approach requires that independent variables should be stationary either at level, I(0), or at first difference, I(1), or mixture of both; but none of the variables should be integrated of order two, I(2). For the purpose of testing unit root, this study relies on Augmented Dickey-Fuller (ADF) test proposed by Dickey and Fuller (1979), and Phillips-Perron (P-P) test proposed by Phillips and Perron 
(1988). The results of unit root tests are reported in Table 3 taking into account both trend and intercept, and intercept only.

Panel A in Table 3 shows the results of ADF test and Panel B shows the results of PP tests. Both tests suggest that all the variables are stationary at first difference while considering intercept only since the all test statistics are significant at 1 percent level. While considering both trend and intercept, 'LnTRADE' is stationary at level, and all other variables are stationary at first difference. These results are significant at 5 percent and 1 percent level, respectively. Thus, the results of unit root test support the precondition of ARDL bounds test as such that variables of interest are either $\mathrm{I}(0)$ or $\mathrm{I}(1)$, but none of them are $\mathrm{I}(2)$.

\section{Results of general ARDL model and ARDL bounds test}

This section investigates the possibility of the existence of long-run relationship between dependent variable 'LnGDP', and independent variables 'LnTRADE', 'LnINV' and 'LnPOP' in the multivariate ARDL framework of the ARDL bounds testing approach. According to this approach, first we obtain the appropriate lag order on the first differenced variables in Equations (6) by using the Akaike Information Criterion (AIC).

Table 4: Estimates for the general ARDL(3, 0, 1,3) model

\begin{tabular}{lcccc}
\hline \multicolumn{1}{c}{ Variable } & Coefficient & Std. Error & t-Statistic & p-Value \\
\hline LnGDP(-1) & $0.3766^{* *}$ & 0.1539 & 2.4478 & 0.0202 \\
LnGDP(-2) & -0.0939 & 0.1755 & -0.5350 & 0.5965 \\
LnGDP(-3) & $0.5042^{*}$ & 0.1480 & 3.4061 & 0.0018 \\
LnTRADE & $0.0648^{* *}$ & 0.0257 & 2.5153 & 0.0173 \\
LnINV & 0.0054 & 0.0389 & 0.1389 & 0.8904 \\
LnINV(-1) & 0.0735 & 0.0450 & 1.6335 & 0.1125 \\
LnPOP & $-0.7968^{*}$ & 0.1508 & -5.2825 & 0.0000 \\
LnPOP(-1) & 0.3600 & 0.2363 & 1.5235 & 0.1378 \\
LnPOP(-2) & -0.1349 & 0.2440 & -0.5530 & 0.5842 \\
LnPOP(-3) & $0.5441^{* *}$ & 0.1985 & 2.7414 & 0.0101 \\
C & $1.0092^{*}$ & 0.3297 & 3.0607 & 0.0045 \\
\hline R-squared & 0.9970 & Mean dependent var. & 9.8085 \\
Adjusted R-squared & 0.9961 & S.D. dependent var. & 0.3220 \\
S.E. of regression & 0.0202 & Akaike info criterion & -4.7428 \\
F-statistic & $1035.3610^{*}$ & & & \\
\hline
\end{tabular}

Source: Author's calculation using the data derived from sources described in Section 2.

Using automatic lag selection in ARDL model and setting maximum lag length at 3 for both dependent and independent variables, the selected general ARDL model with no 
serial correlation in multivariate framework is $\operatorname{ARDL}(3,0,1,3)$ model. In automatic lag selection process, the maximum lag has been set at 3 because higher order of lag may result into loosing greater degree of freedom in case of small sample size. The estimates of the general ARDL $(3,0,1,3)$ are reported in Table 4.

Before providing an estimate of long-run coefficients, it is necessary to confirm the existence of long-run relationship among the variables of interest. Therefore, in the second step, we apply ARDL bounds test to Equation (6) for the $\operatorname{ARDL}(3,0,1,3)$ model to confirm the existence of co-integration among variables. The results of the ARDL bounds F-test are reported in Table 5. As reported in Table 5, the F-statistic for ARDL bounds test is 13.04, which is greater than upper bound critical value at 1 percent level $(3.65,4.66)$. It implies that there is sufficient evidence to reject the null of no co-integration. Thus, the results of the ARDL bounds F-test suggest that there exists a long-run relationship between LnGDP, LnTRADE, LnINV and LnPOP over the period mid-July 1975-2019. In other words, these variables tend to have long-run equilibrium and they tend to move together in the long-run. However, this result should be considered preliminary, and simply indicates that there is longrun relationship among variables under investigation. Hence, $\operatorname{ARDL}(3,0,1,3)$ model can be applied to estimate the long-run and short-run dynamics of the relationship between dependent and independent variables.

Table 5: Results of the ARDL bounds test

\begin{tabular}{cccc}
\hline Test Statistic & Value & $\mathbf{k}$ \\
\hline F-stat & 13.04 & 3 \\
\hline Significance & Critical Value Bounds \\
\hline $10 \%$ & Lower Bounds & Upper Bounds \\
$5 \%$ & 2.37 & 3.20 \\
$2.5 \%$ & 2.79 & 3.67 \\
$1 \%$ & 3.15 & 4.08 \\
& & 3.65 & 4.66 \\
\hline
\end{tabular}

Note: ' $k$ ' stands for the number of regressors.

Source: Author's calculation using the data derived from sources described in Section 2.

\section{Results of long-run estimates and error correction representation}

After having confirmed the presence of long-run relationship, we estimate the longrun coefficients and error correction representation of the selected $\operatorname{ARDL}(3,0,1,3)$ model. The long-run results of the ARDL $(3,0,1,3)$ model are reported Table 6. 
The long-run results reported in Table 6 show that the coefficient of trade openness (LnTRADE) is positive and statistically significant at 5 percent level. The results particularly show that level of Nepal's trade openness leads to an increase in economic growth in the long run. It implies that a 1 percentage increase in total value of foreign trade leads to 0.3039 percentage increase in GDP. This documentation is consistent to various previous studies in recent periods (for example, Nowbutsing, 2014; Keho, 2017; Malefane and Odhiambo, 2018, among others), which show that the level of trade openness affects positively the rate of economic growth of a country in the long-run.

Table 6: Results of long-run estimates for the $\operatorname{ARDL}(3,0,1,3)$ model Dependent variable: LnGDP

\begin{tabular}{lcccc}
\hline \multicolumn{1}{c}{ Variable } & Coefficient & Std. Error & t-Statistic & p-Value \\
\hline LnTRADE & $0.3039^{* *}$ & 0.1302 & 2.3349 & 0.0262 \\
LnINV & $0.3705^{* *}$ & 0.1583 & 2.3404 & 0.0259 \\
LnPOP & -0.1296 & 0.4348 & -0.2981 & 0.7676 \\
C & $4.7362^{*}$ & 0.3165 & 14.9659 & 0.0000 \\
\hline \multicolumn{4}{c}{ EC = LnGDP - $(0.3039$ x LnOPEN + 0.3705 x LnINV $-0.1296 \times$ LnPOP + 4.7362 ) } \\
Note: “*” signs indicates that results are significant at 1 percent level, and “**” signs indicate \\
that results are significant at 5 percent level. \\
Source: Author's calculation using the data derived from sources described in Section 2.
\end{tabular}

The long-run results associated with the effects of other variables show the mixed results. The coefficient of investment (LnINV) is also positive and significant at 5 percent level indicating that the level of investment impacts positively the economic growth in Nepal in the long-run. Particularly, a 1 percentage increase in level of real investment in the economy leads to 0.3705 percentage increase in GDP. This documentation is consistent to the notion of trade-induced investment growth of Seghezza and Baldwin (2008), which articulates that trade openness impacts the level of economic growth through the positive effect of investment. However, contrary to the expectations of this study and the notion of endogenous growth model, the coefficient of the stock of human capital (LnPOP) is negative though not significant. Nepal is basically a low-income country. Therefore, the negative coefficient of 'LnPOP' can be interpreted in consistent to Peterson (2017) that higher population growth in a low income country obstructs its economic development process, though the coefficient is not statistically significant.

Table 7 shows the short-run dynamics of error correction representation of the $\operatorname{ARDL}(3,0,1,3)$ model. Importantly, the coefficient of lagged error correction term, ECT(-1), is statistically significant at 1 percent level with correct negative sign. The coefficient of error 
correction term $(-0.2131)$ shows the speed of adjustment toward long-run equilibrium if any disequilibrium exists in the short-run. The results show that any deviations in the short-run are corrected towards the long-run equilibrium with the speed of adjustment of 21.31 percent each year. This low speed of adjustment in output growth might be due to the low volume of exports as compared to imports. Based on long-run results, it can be referred that overall trade openness in Nepal can stimulate economic growth in the long-run. Thus, the policy implication of these results for Nepal is that considerable efforts should be initiated to stimulate the export growth in the line with import to promote economic growth in Nepal.

Table 7: Error correction representation for the $\operatorname{ARDL}(3,0,1,3)$ model Dependent variable: D(LnGDP)

\begin{tabular}{lcccc}
\hline \multicolumn{1}{c}{ Variable } & Coefficient & Std. Error & t-Statistic & p-Value \\
\hline$\Delta($ LnGDP(-1) $)$ & $-0.4103^{*}$ & 0.1272 & -3.2264 & 0.0030 \\
$\Delta($ LnGDP(-2) $)$ & $-0.5042^{*}$ & 0.1359 & -3.7094 & 0.0008 \\
$\Delta($ LnINV) & 0.0054 & 0.0337 & 0.1608 & 0.8733 \\
$\Delta($ LnPOP $)$ & $-0.7968^{*}$ & 0.1235 & -6.4520 & 0.0000 \\
$\Delta($ LnPOP(-1) $)$ & $-0.4092^{* *}$ & 0.1629 & -2.5115 & 0.0174 \\
$\Delta($ LnPOP(-2) $)$ & $-0.5441^{*}$ & 0.1740 & -3.1271 & 0.0038 \\
ECT & $\mathbf{- 0 . 2 1 3 1 *}$ & $\mathbf{0 . 0 2 4 8}$ & $\mathbf{- 8 . 5 7 9 1}$ & $\mathbf{0 . 0 0 0 0}$ \\
\hline R-squared & 0.7436 & Mean dependent var. & 0.0246 \\
Adjusted R-squared & 0.6997 & S.D. dependent var. & 0.0347 \\
S.E. of regression & 0.0190 & Akaike info criterion & -4.9333 \\
F-statistic & $14.0896^{*}$ & & & \\
\hline
\end{tabular}

Note: “*” signs indicates that results are significant at 1 percent level, and “**” signs indicate that results are significant at 5 percent level.

Source: Author's calculation using the data derived from sources described in Section 2.

\section{Results of residuals diagnostic and stability check of the model}

Table 8: Residual diagnostic tests for the $\operatorname{ARDL}(3,0,1,3)$ model

\begin{tabular}{lcll}
\hline Serial Correlation LM Test: Breusch-Godfrey & & \\
F-statistic & 1.5625 & p-value F $(3,28)$ & 0.2205 \\
Obs*R-squared & 6.0228 & p-value Chi-Square(3) & 0.1105 \\
\hline Heteroskedasticity Test: Breusch-Pagan-Godfrey & & \\
F-statistic & 1.6002 & p-value F $(10,31)$ & 0.1529 \\
Obs*R-squared & 14.2992 & p-value Chi-Square(10) & 0.1598 \\
\hline Jarque-Bera & 5.2710 & p-value & 0.0717 \\
\hline Source: Author's calculation using the data derived from sources described in Section 2. \\
Finally, the results of diagnostic tests have been reported to confirm the adequacy of \\
the model specifications. The results of diagnostic tests of the ARDL(3,0,1, 3) model are
\end{tabular}


reported in Table 8. The results of diagnostic tests suggest that long run and short-run estimates are free from serial correlation, heteroscedasticity, and non-normality of the model residuals.

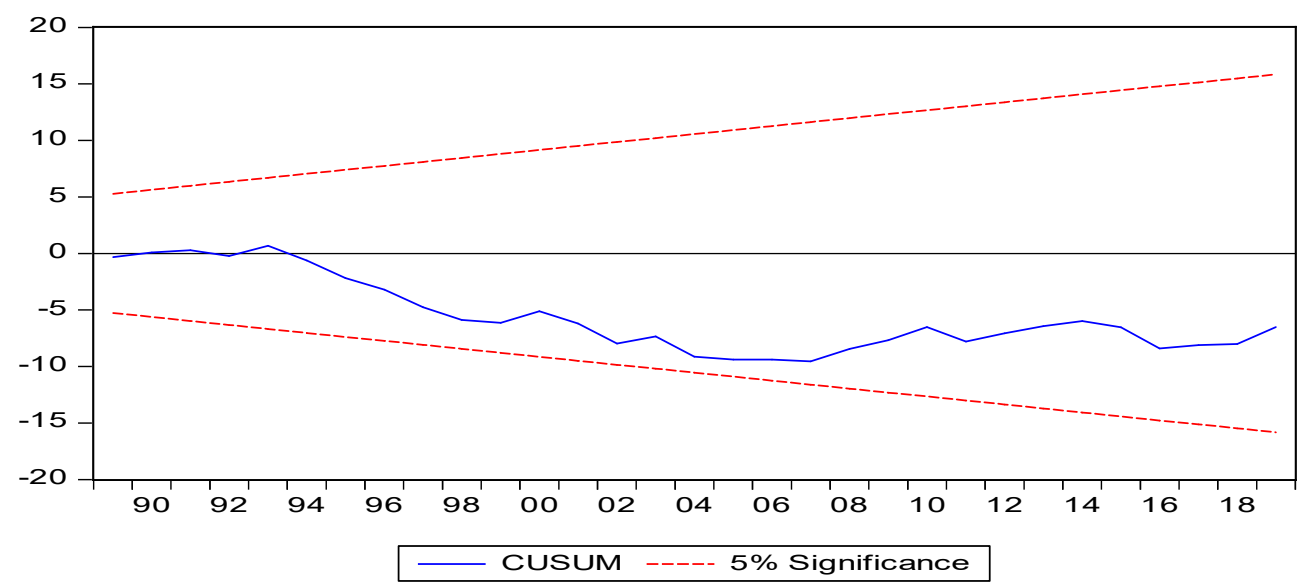

Figure 2: Plot of CUSUM test

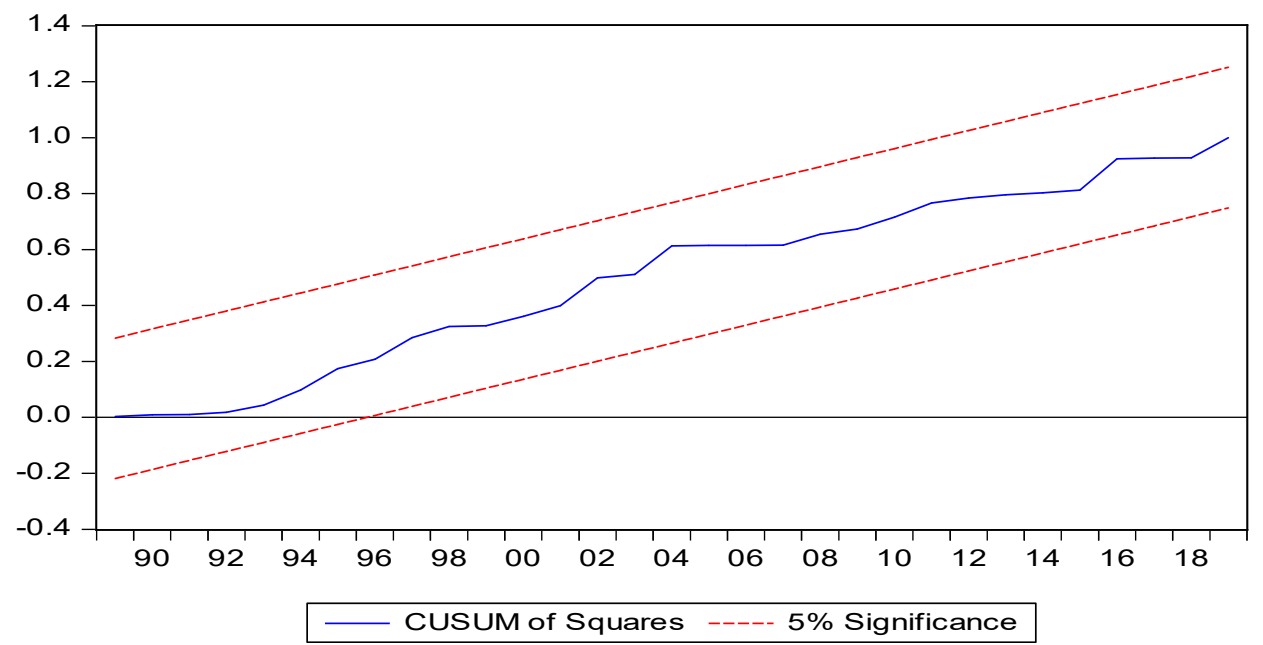

Figure 3: Plot of CUSUMSQ test

Further, the stability of the ARDL parameters was tested by applying the CUSUM and CUSUMSQ tests developed by Brown, Durbin and Evans (1975). Figure 2 and Figure 3 show plots of the cumulative sum of recursive residuals (CUSUM) and cumulative sum of squares of recursive residuals (CUSUMSQ), respectively. These results show that the ARDL 
parameters are stable because graphs of the CUSUM and CUSUMSQ are within the critical bounds at the 5 percent level of significance. Thus, the model is stable and it confirms the stability of the long-run coefficients of the regressors.

\section{CONCLUSION AND IMPLICATIONS}

This study examined the impact of trade openness on economic growth in Nepal over the period 1975-2019. The study applied multivariate ARDL bounds testing approach to cointegration in the framework of endogenous growth model to capture long-run and short run dynamics of the relationship between trade openness and economic growth in Nepal. The results of ARDL bounds test revealed that economic growth variable and the independent variables of interest are co-integrated supporting the hypothesis that there exists long-run relationship between economic growth and trade openness in Nepal over the study period. The long-run estimates of ARDL model showed that the level of trade openness in Nepal predicts the rate of economic growth of the country in the long-run. The positive and significant coefficient of trade openness variable implies that trade openness in Nepal positively affects the economic growth in the long-run. The basic documentation of this study is compatible to the trade-led growth hypothesis and confirms to many of the previous studies such as Bodman (1996), Chang et al. (2009), Nowbutsing (2014), Keho (2017), and Malefane and Odhiambo (2018), among others.

The study also reported the positive and significant long-run effect of level of investment on growth in Nepal over the study period. This result confirms to trade-induced investment growth, which supports the notion that trade openness affects economic growth through the channel of investment. However, contrary to the expectations of this study, the stock of human capital has negative impact on growth though the effect is not significant. The negative effect of human capital implies that Nepal is still not capable of generating and developing growth enhancing human resources in the country. Besides, the results of error correction representation of this study showed significant error correction terms with correct sign, which shows that long-run equilibrium between the variables of interest are stable and any disequilibrium that exists in the short-run will adjust to equilibrium in the long-run. However, the speed of adjustment towards long-run equilibrium is lower, which is possibly attributed to low value of exports. Thus, the policy implication of these results for Nepal is that considerable efforts should be initiated to stimulate the export growth. 
Overall, the growth enhancing role of foreign trade implies that Nepal Government should promote international trade by eliminating trade barriers and making the procedures of foreign trade simple and convenient. As a matter of fact, Nepal's foreign trade is heavily loaded by imports. Therefore, high value of imports as compared to exports has created large amount of trade deficits over the years, which has threatened country's fiscal sustainability. Therefore, it is necessary for Nepal to search the areas of strategic and competitive advantages in its export markets, which may be accomplished by modifying trade and switching from exports of one type of product to other. Moreover, as the study results showed the level of foreign trade affects through the channel of investment, Nepal's import policy should promote investment environment particularly in capital intensive sectors to take the advantage of technology transfer from technologically advanced country. Besides, Nepal should pay proper attention and come up with effective human resource development policy that can uplift human knowledge and skills to make use of technologies from developed countries. Finally, this study left to investigate the comparative role of imports and exports in accelerating growth. Therefore, future studies should take into account this issue to understand the comparative role of imports and exports in fostering Nepal's economic growth.

\section{REFERENCES}

Barro, R. J., \& Sala-i-Martin, X. (1997). Technological diffusion, convergence, and growth. Journal of Economic Growth, 2(1), 1-26. https://doi.org/10.1023/A:1009746629269.

Beddies, C. (1999). Investment, capital accumulation, and growth: Some evidence from Gambia 1964-98. IMF Working Paper No. 99/117. International Monetary Fund, Washington, DC, United States.

Bodman, P. M. (1996). On export-Led growth in Australia and Canada: Co-integration, causality and structural stability. Australian Economic Papers, 35(67), 282-299.

Brown, R. L., Durbin, J., \& Evans, M. (1975). Techniques for testing the constancy of regression relations over time. Journal of the Royal Statistical Society, 37, 149-163.

Chang, R., Kaltani, L., \& Loayza, N. V. (2009). Openness can be good for growth: The role of policy complementarities. Journal of Development Economics, 90, 33-49. https://doi.org/10.1016/j.jdeveco.2008.06.011.

Coe, D. T., \& Helpman, E. (1995). International R\&D spillovers. European Economic Review, 39(5), 859-887. https://doi.org/10.1016/0014-2921(94)00100-E.

Dickey, D. A., \& Fuller, W. A. (1979). Distribution of the estimators for autoregressive time series with a unit root. Journal of the American Statistical Association, 74(366), 427-431. 
Ghura, D. (1997). Private investment and endogenous growth: Evidence from Cameroon. IMF Working Paper No. 97/165. International Monetary Fund, Washington DC, United States.

Gries, T., Kraft, M., \& Meierrieks, D. (2009). Linkages between financial deepening, trade openness, and economic development: Causality evidence from Sub-Saharan Africa. World Development, 37(2), 1849-1860. https://doi.org/10.1016/j.worlddev.2009.05.008

Grossman, G., \& Helpman, E. (1990). Comparative advantage and long-run growth. American Economic Review, 80(4), 796-815.

Huang, L. C., \& Chang, S. H. (2014). Revisit the nexus of trade openness and GDP growth: Does the financial system matter? The Journal of International Trade \& Economic Development, 23(7), 1038-1058. https://doi.org/10.1080/09638199.2013.830638.

Johansen, S., \& Juselius, K. (1990). Maximum likelihood estimation and inference on cointegration with application for the demand for money. Oxford Bulletin of Economics and Statistics, $52,169-210$.

Keho, Y. (2017). The impact of trade openness on economic growth: The case of Cote d'Ivoire. Cogent Economics and Finance, 5(1), 1-14. https://doi.org/10.1080/23322039.2017.1332820.

Kim, D. H., Lin, S. C., \& Suen, Y. B. (2011). Nonlinearity between trade openness and economic development. Review of Development Economics, 15(2) 279-292. https://doi.org/10.1111/rode.2011.15.

King, R. G., \& Levine, R. (1993). Finance, entrepreneurship and growth: Theory and evidence. The Journal of Monetary Economics, 32(3), 513-542.

Levine, R., \& Zervos, S. (1996). Stock market development and long-run growth. The World Bank Economic Review, 10(2), 323-339.

Levine, R., \& Zervos, S. (1998). Stock market, banks, and economic growth. American Economic Review, 88(3), 537-558.

Malefane, M. R., \& Odhiambo, N. M. (2018). Impact of trade openness on economic growth: Empirical evidence from South Africa. International Economics, 71(4), 387-416.

McCarville, M., \& Nnadozie, E. (1995). Causality tests of export led growth: The case of Mexico. Atlantic Economic Journal, 23(2), 140-145.

Nowbutsing, B. M. (2014). The impact of openness on economic growth: Case of Indian Ocean RIM countries. Journal of Economics and Development Studies, 2(2), 407-427.

Odhiambo, N. M. (2011). Financial intermediaries versus financial markets: A South African experience. International Business \& Economics Research Journal, 10 (2), 77-84. https://doi.org/10.19030/iber.v10i2.1795

Pesaran, H. M., \& Shin, Y. (1995). Autoregressive distributed lag modeling approach to cointegration analysis. DAE Working Paper Series No. 9514. Department of Applied Economics, University of Cambridge.

Pesaran, M. H., Shin, Y., \& Smith, R. J. (2001). Bounds testing approaches to the analysis of level relationships. Journal of Applied Economics, 16(3), 289-326. 
Peterson, E. W. F. (2017). The role of population in economic growth. Faculty Publications: Agricultural Economics, 171. Retrieved from https://digitalcommons.unl.edu/ageconfacpub/171.

Phillips, P. C. B., \& Perron, P. (1988). Testing for unit root in time series regression. Biometrika, 75(2), 335-346.

Rassekh, F. (2007). Is international trade more beneficial to lower income economies? An empirical inquiry. Review of Development Economics, 11(1), 159-169. https://doi.org/10.1111/rode.2007.11.

Rigobon, R., \& Rodrik, D. (2005). Rule of law, democracy, openness, and income: Estimating the interrelationships. The Economics of Transition, 13(3), 533-564. https://doi.org/10.1111/ecot.2005.13.

Rivera-Batiz, L., \& Romer, P. (1991). International trade with endogenous technological change. European Economic Review, 35(4), 971-1001. https://doi.org/10.1016/00142921(91)90048-N.

Romer, P. (1990). Endogenous technological change. Journal of Political Economy, 98(5), 71-102. https://doi.org/10.1086/261725.

Seghezza, E., \& Baldwin, R. E. (2008). Testing for trade-induced investment-led growth. International Economics, 61(2-3), 507-537.

Sengupta, J. K., \& Espana, J. R. (1994). Exports and economic growth in Asian NICs: An econometric analysis of Korea. Applied Economics, 26(1), 41-51. https://doi.org/10.1080/00036849400000060.

Simon, J. L. (1990). Population Matters: People, Resources, Environment, and Immigration. New Brunswick, NJ: Transaction Publishers.

Tekin, R. B. (2012). Development aid, openness to trade and economic growth in least developed countries: Bootstrap panel granger causality analysis. Procedia-Social and Behavioral Sciences, 62, 716- 721. https://doi.org/10.1016/j.sbspro.2012.09.121

Ulaşan, B. (2015). Trade openness and economic growth: Panel evidence. Applied Economics Letters, 22(2), 163-167. https://doi.org/10.1080/13504851.2014.931914

Vamvakidis, A. (2002). How robust is the growth-openness connection: Historical evidence. Journal of Economic Growth, 7(1), 57-80. https://doi.org/10.1023/A:1013418610712

Yanikkaya, H. (2003). Trade openness and economic growth: A cross-country empirical investigation. Journal of Development Economics, 72(1), 57-89. https://doi.org/10.1016/S0304-3878(03)00068-3 